\title{
Spatiotemporal response of the water cycle to land use conversions in a typical hilly-gully basin on the Loess Plateau, China
}

\author{
Linjing Qiu ${ }^{1}$, Yiping Wu ${ }^{1}$, Lijing Wang ${ }^{1}$, Xiaohui Lei ${ }^{2}$, Weihong Liao ${ }^{2}$, Ying Hui ${ }^{3}$, and Xianyong Meng ${ }^{2}$ \\ ${ }^{1}$ Department of Earth and Environmental Science, School of Human Settlements and Civil Engineering, \\ Xi' an Jiaotong University, Xi'an, Shaanxi, China \\ ${ }^{2}$ State Key Laboratory of Simulation and Regulation of Water Cycle in River Basin, China Institute of Water Resources \\ and Hydropower Research, Beijing, China \\ ${ }^{3}$ Meteorological Institute of Shaanxi Province, Xi'an, Shaanxi, China
}

Correspondence: Yiping Wu (yipingwu@xjtu.edu.cn)

Received: 17 June 2017 - Discussion started: 23 June 2017

Revised: 10 November 2017 - Accepted: 13 November 2017 - Published: 20 December 2017

\begin{abstract}
The hydrological effects of the "Grain for Green" project (GFGP) on the Loess Plateau have been extensively debated due to the complexity of the water system and its multiple driving factors. The aim of this study was to investigate the response of the hydrological cycle to the GFGP measures based in a case study of the Yanhe Basin, a typical hilly-gully area on the Loess Plateau of China. First, we analyzed the land use and land cover (LULC) changes from 1990 to 2010. Then, we evaluated the effects of LULC changes and sloping land conversion on the main hydrological components in the basin using the Soil and Water Assessment Tool (SWAT). The results indicated that cropland exhibited a decreasing trend, declining from $40.2 \%$ of the basin area in 1990 to $17.6 \%$ in 2010 , and that the woodland and grassland areas correspondingly increased. With the land use changes from 1990 to 2010, the water yield showed a decreasing trend which was mainly due to decrease in surface runoff. In contrast, evapotranspiration (ET) showed an increasing trend over the same period, resulting in a persistent decrease in soil water. The conversion of sloping cropland to grassland or woodland exerted negative effects on water yield and soil water. Compared with the land use condition in 2010, the negative effects were most evident where cropland with a slope $\geq 15^{\circ}$ was converted to woodland, with decreases in surface runoff and soil water of 17.1 and $6.4 \%$, respectively. These results suggest that the expansive reforestation on sloping land in the loess hilly-gully region decreased water yield and increased ET, resulting in reduced soil water. The results of this study can be used to support sustain-
\end{abstract}

able land use planning and water resource management on the Loess Plateau in China.

\section{Introduction}

Land surface change is one of the most important drivers of ecohydrological changes (Li et al., 2009; Blöschl et al., 2007). The impacts of land use and land cover (LULC) changes on water resources and hydrological processes in a river basin are mainly reflected in the overland surface runoff, streamflow, evapotranspiration (ET), and soil water (Bari and Smettem, 2004; Chawla and Mujumdar, 2015; Liu et al., 2008b; Zucco et al., 2014). Many studies have investigated the relationships between land use patterns and basin hydrology and have found that the characteristics of basin hydrology vary among land use patterns due not only to the type of LULC (Wang et al., 2012; Jian et al., 2015; Duan et al., 2016) but also to the spatiotemporal heterogeneity of LULC (Chu et al., 2010; Liu et al., 2013). However, debate exists among ecohydrologists regarding the effects of past and ongoing land use changes because of the spatial and temporal complexity of hydrological processes (Lørup et al., 1998; López-Moreno et al., 2011; Alkama et al., 2013; Liu et al., 2016).

Land use planning in China is considered a crucial strategy for the sustainable management of river basin systems and has been widely adopted for ecological restoration and water resource protection, especially in the Loess Plateau re- 
gion, which is well known for its fragile ecology (Liu et al., 2008a; Zhang et al., 2009; Zhen et al., 2014). The river basins on the Loess Plateau are important because of the dense population, intensive cultivation, and the high demand for water in the area. Unfortunately, this region is characterized by insufficient water resources and severe soil erosion, and it has historically experienced vegetation degradation and desertification (Zhao et al., 2013; Guo et al., 2002). Thus, land use change and basin hydrology have attracted considerable attention, and since the 1970s, soil and water conservation practices have been implemented in the area to mitigate the increasing environmental problems. In 1999, the "Grain for Green" project (GFGP) was launched by the Chinese government in the Loess Plateau region with the primary goal of retiring and converting steep cropland (slope $\geq 15^{\circ}$ ) to green lands (Zhou et al., 2012; Liu et al., 2008a). It was reported that the vegetation coverage on the Loess Plateau increased from $6.5 \%$ in the 1970 s to $51 \%$ in 2010 (Wang et al., 2012), and approximately $16000 \mathrm{~km}^{2}$ of rain-fed cropland was converted to planted vegetation during the past decade (Feng et al., 2016). Consequently, the hydrological processes on the sloping land and in the river systems have changed, but the extent of these changes and their relationships to LULC change remain unclear.

In the past decades, the hydrological effects of land use change have been widely explored across different spatiotemporal scales on the Loess Plateau. Huang et al. (2003) investigated the runoff response to afforestation using a paired watershed analysis and revealed that forest revegetation reduced annual runoff, with the reduction amount increasing with tree age. McVicar et al. $(2007,2010)$ developed a decision support tool for China's revegetation program and simulated annual streamflow based on revegetation planning. Wei et al. (2015) found a strong inverse relationship between runoff and conversion to forests, shrubs, and grasses during the period 2005-2010 in a typical watershed on the Loess Plateau. Feng et al. (2016) reported that revegetation increased ET and resulted in a significant $(P<0.001)$ decrease in the ratio of streamflow to precipitation on the Chinese Loess Plateau. Zuo et al. (2016) combined statistical tests and hydrological modeling to assess the effects of land use on runoff and found that the water resources in the upstream region decreased more than did those in the downstream region. Liang et al. (2015) used an elasticity and decomposition model based on the Budyko framework to simulate and forecast the hydrological effects of ecological restoration and demonstrated that ecological restoration played a dominant role in the reduction of streamflow in 14 main sub-basins on the Chinese Loess Plateau. Another study showed that the GFGP can potentially increase soil water content and water yield and decrease runoff and ET (Tian et al., 2016). Moreover, some researchers have reported that woody species consume more water by ET than do other vegetation types (Wang et al., 2012; Yang et al., 2014), and some studies have documented that large-scale reforestation has greatly decreased the water yield and exacerbated water scarcity (Sun et al., 2006), gradually leading to soil desiccation (Chen et al., 2007, 2008; Wang et al., 2008). In general, these studies indicated that the GFGP on the Loess Plateau has had an evident influence on basin hydrology; however, because these studies were performed from different perspectives or concentrated on single hydrological elements, the effects of ecosystem restoration on water balance have not been clarified. In addition, most previous studies have been based on statistical methods and short timescales. Although numerical models are useful tools for quantitatively assessing the hydrological responses to environmental changes, the previous modeling studies mainly focused on water discharge in river channel, with few studies focused on the spatial features of hydrological responses. Spatially studying such responses could improve watershed management and the development of strategies for water resource optimization. Therefore, a comprehensive understanding of how LULC change and spatial heterogeneity in LULC affect the water balance is essential for long-term land use planning and water resource management.

In this study, the Soil and Water Assessment Tool (SWAT) was applied to investigate the hydrological impacts of land use changes, including those resulting from the sloping land conversion (SLC) program, on the Loess Plateau. The Yanhe Basin, a main tributary of the middle reach of the Yellow River that has undergone large-scale revegetation and SLC, was selected for analyzing the hydrological responses via modeling. The specific objectives were as follows: (1) investigate the spatiotemporal variations in key water balance components as a result of LULC change, (2) evaluate the potential effects of land conversion on water availability under the SLC program, and (3) examine the changes in soil water storage under different land use conditions.

\section{Materials and methods}

\subsection{Study area}

The Yanhe Basin, which is located in the northern Shaanxi province, China $\left(36^{\circ} 21^{\prime}-37^{\circ} 19^{\prime \prime} \mathrm{N}\right.$ and $\left.108^{\circ} 38^{\prime}-110^{\circ} 29^{\prime} \mathrm{E}\right)$, is a typical hilly loess area on the Loess Plateau. The drainage area of the basin is $7591 \mathrm{~km}^{2}$, and its elevation ranges from 560 to $1760 \mathrm{~m}$ (Fig. 1). The slope of the basin varies from 0 to $85.3^{\circ}$, with a mean value of $17.7^{\circ}$. The main channel of the Yanhe River is $284.3 \mathrm{~km}$ long and originates in Jingbian County. It flows from northwest to southeast through Zhidan County, Ansai District, Yan'an, and Yanchang County before entering the Yellow River. The soil in the basin developed from loess deposits, and the dominant soil type is loessial soil which is classified as Calcaric Cambisols (FAO, 2014). The Yanhe Basin is characterized by a semi-arid continental climate with warm and concentrated precipitation in summer and cold, dry winters with occasional snowfall. Accord- 


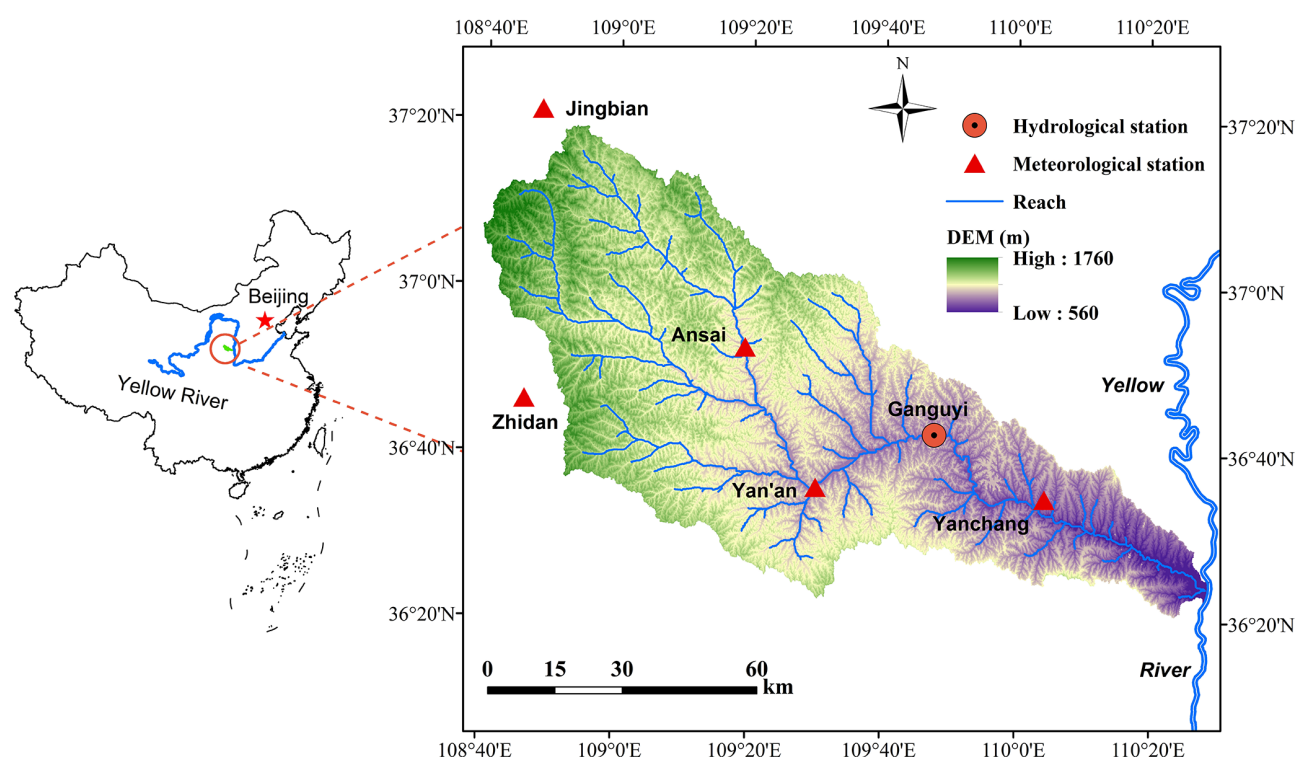

Figure 1. Map of the Yanhe Basin showing the elevation and the locations of the meteorological and hydrological stations.

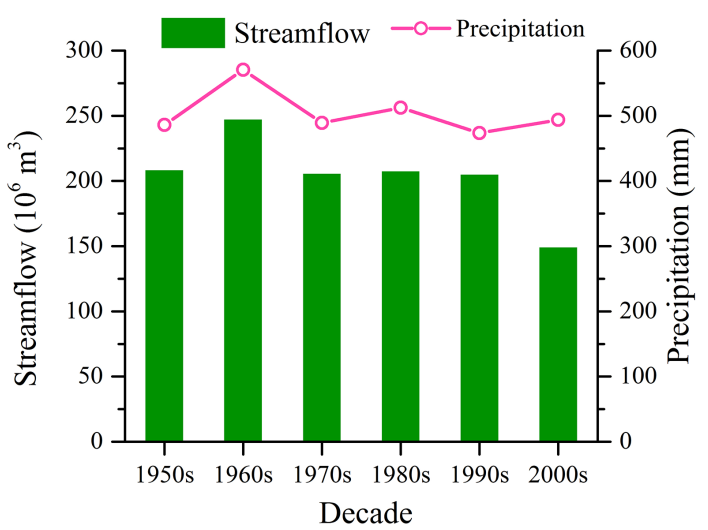

Figure 2. Precipitation and streamflow changes in different decades in the Yanhe Basin.

ing to the collected meteorological data from the Meteorological Institute of Shaanxi Province, China, the precipitation during 1952-2015 ranged from 300 to $803 \mathrm{~mm}$, with a mean annual value of $495 \mathrm{~mm}$. Additionally, the mean annual maximum and minimum air temperatures over this period were 17.4 and $4.2^{\circ}$, respectively. Grassland, cropland, and woodland (mainly artificial woods) are the dominant land use types in this region. Most crops are cultivated on sloping lands, and woodlands are generally located on the steeper parts of the landform. The mean annual streamflow at the most downstream station of Ganguyi was $205 \times 10^{6} \mathrm{~m}^{3}$ from 1952 to 2008, and the streamflow from June to September accounted for $64.1 \%$ of the total annual discharge at this station. The GFGP was implemented in the basin in 1999, and the observed streamflow showed a decreasing trend during the 2010s (Fig. 2).

\subsection{Data}

The SWAT model setup requires data inputs including topography, soil, land use, climate, and streamflow discharge. A digital elevation model (DEM) of the basin with a $30 \mathrm{~m}$ resolution was obtained from the National Geomatics Center of China (http://www.ngcc.cn/). A soil survey map with $20 \mathrm{~m}$ resolution was obtained from the Institute of Soil and Water Conservation (ISWC), Chinese Academy of Sciences (CAS), and we developed a user soil database required for the model that linked to the digital soil map using ArcGIS (version 10.2). LULC data from 1990, 2000, and 2010 with $30 \mathrm{~m}$ resolution were supplied by the Institute of Remote Sensing and Digital Earth, CAS, and the land use was classified into six types according to the ecosystem classification system of China: grassland, woodland, cropland, water, residential land, and barren land. Required meteorological data for the SWAT model comprise daily precipitation, maximum and minimum temperature, relative humidity, wind speed, and solar radiation, which were available from 1980 to 2015 from five county-level meteorological stations: Jingbian, Zhidan, Ansai, Yan'an, and Yanchang. These data were provided by the Meteorological Institute of Shaanxi Province, China. Observed monthly streamflow data at the Ganguyi hydrological station were obtained from the Yellow River Conservancy Commission (YRCC) from 1980 to 2010. The data were used for model calibration and validation, although some data gaps (missing values) were present. Ganguyi station is the most downstream station on the Yanhe River and controls an area of $5891 \mathrm{~km}^{2}$. 


\subsection{Model description}

The SWAT model (version 2012), which was developed by the US Department of Agriculture (USDA) - Agricultural Research Services (ARS), is a physically based, temporally continuous, and distributed watershed-scale hydrological model (Neitsch et al., 2011; Douglas-Mankin et al., 2010). The SWAT-modeled hydrological cycle is based on the water balance, as documented by Arnold et al. (1998). SWAT has been widely tested and successfully used to explore the effects of climate and land use/management changes on watershed hydrology and water quality (Nyeko, 2015; Panagopoulos et al., 2011; Douglas-Mankin et al., 2010; Zhang et al., 2013; Bosch et al., 2010; Wu and Chen, 2013; Xu et al., 2012; Zhang et al., 2008, 2011; Qiu et al., 2012; Gassman et al., 2014). Detailed descriptions of the mechanisms and structure of the SWAT model can be found elsewhere (Neitsch et al., 2011; Arnold et al., 2012).

\subsection{Model setup and calibration/validation}

A Geographic Information System (GIS) interface, ArcSWAT (Version 2012), was used to set up the model. The DEM was used to delineate the watershed with a threshold sub-basin area of $50 \mathrm{~km}^{2}$, resulting in 88 sub-basins. Then, the land use map of 1990 and the soil map were imported and overlaid to create the hydrological response units (HRUs). HRUs are portions of a sub-basin that represent unique combinations of land use, soil, and slope. To accurately reflect the spatial variability in the basin, multiple HRUs were selected using a minimum threshold value of $5 \%$ for each land use, soil, and slope category, resulting in 1136 HRUs. To meet the needs of the model, the SWAT codes for the main land use types in the study area were defined as cropland (AGRR), woodland (FRST), grassland (RNGE), residential land (URBN), and barren land (BARR) in the attribute data. The SWAT model was calibrated using monthly streamflow data from the Ganguyi hydrological station, and we adopted the SWAT-CUP (SUFI-2) program to perform a sensitivity analysis of model parameters. Calibration was conducted using the first 10-year (1983-1992) record of streamflow, and the model was then validated using data from the subsequent 8 years (1993-2000). Additionally, a 3-year warm-up period (1980-1982) was used to minimize the effects of uncertain initial conditions (e.g., soil water storage) in the model simulation. To evaluate the model performance numerically, we used three statistical measures: percent bias (PBIAS), NashSutcliffe efficiency (NSE) (Nash and Sutcliffe, 1970), and the coefficient of determination (squared correlation coefficient, $r^{2}$ ). Typically, a model simulation is considered satisfactory with NSE $>0.5,-25 \% \leq$ PBIAS $\leq 25 \%$, and $r^{2}>0.5$ (Neupane and Kumar, 2015; Wu and Chen, 2013).

\subsection{Historical land use change and hydrological simulation}

To understand the historical land use change of the Yanhe Basin, we conducted the spatiotemporal analysis of land use change using three land use conditions (land use maps from 1990, 2000, and 2010, corresponding to LU1990, LU2000, and LU2010, respectively), and the amount of specific land use types that changes from the initial time to the subsequent time was identified by overlaying the land use maps for different years. Then, the different land use data were taken as input of the calibrated SWAT model to isolate the effect of land use change under the historical climate from 1986 to 2015. Finally, the main hydrological components of the water cycle (surface runoff, subsurface flow, ET, water yield, and soil water) under different land use conditions were assessed quantitatively at the HRU level.

\subsection{Hypothetical SLC scenarios}

SWAT was applied for assessing the long-term effects of SLC on the hydrological cycle in the Yanhe Basin. The land use condition of 2010 was set as the baseline scenario (BS), and four hypothetical land conversion scenarios depicting the potential land use pattern were reestablished based on the land use of 2010 and the SLC policy of the GFGP. Scenario S1 and scenario S2 involve the conversion of cropland on slopes steeper than $25^{\circ}$ to grassland and woodland, respectively, and scenario S3 and scenario S4 involve the conversion of cropland on slopes greater than or equal to $15^{\circ}$ to grassland and woodland, respectively. To isolate the hydrological effects only caused by different land management, the SWAT model with BS and four hypothetical scenarios were set up and run for 30 years using the historical climate forcing data from 1986 to 2015.

\section{Results}

\subsection{Model performance evaluation}

We performed a global sensitivity analysis to examine $18 \mathrm{pa}-$ rameters that are potentially related to streamflow and identified the nine most sensitive parameters for subsequent model calibration (Table 1). The selected nine parameters represent key hydrological components such as surface runoff, soil water capacity and conductivity, ET, and groundwater recharge in this region. Although the calibrated model slightly underestimated streamflow, the model performance was satisfactory in the calibration period (1983-1992), with NSE, $r^{2}$, and PBIAS values of $0.51,0.71$, and $15.7 \%$, respectively (Fig. 3a). In the 8-year (1993-2000) validation period, the streamflow characteristics were well captured by the calibrated model, with an NSE value of 0.82, although PBIAS indicated a $16.9 \%$ underestimation (Fig. 3b). In both the calibration and validation periods, the underestimation mainly 
Table 1. Sensitive parameters for streamflow simulation and calibrated values.

\begin{tabular}{llrr}
\hline Parameters & Description & $\begin{array}{r}\text { Range } \\
\text { ON2 }\end{array}$ & $\begin{array}{r}\text { Optimized value/ } \\
\text { percent change }\end{array}$ \\
\hline SOL_AWC & Soil conservation service (SCS) runoff curve number & $-20-20 \%$ & $-4.03 \%^{\mathrm{r}}$ \\
SOL_K & Soil saturated hydraulic conductivity $\left(\mathrm{mm} \mathrm{h}^{-1}\right)$ & $-20-20 \%$ & $10.71 \%^{\mathrm{r}}$ \\
ESCO & Soil evaporation compensation factor & $-20-20 \%$ & $7.36 \%^{\mathrm{r}}$ \\
EPCO & Plant uptake compensation factor & $0-1$ & $0.51^{\mathrm{v}}$ \\
ALPHA_BF & Baseflow alpha factor (day) & $0-1$ & $0.65^{\mathrm{v}}$ \\
GWQMN & Threshold depth of water in the shallow aquifer & $0-0.5$ & $0.36^{\mathrm{v}}$ \\
& required for return flow to occur (mm) & $0.05-6$ & $906.20^{\mathrm{v}}$ \\
SURLAG & Surface runoff lag coefficient & $100-1200$ & $2.93^{\mathrm{v}}$ \\
REVAPMN & Threshold depth of water in the shallow aquifer & & $499.40^{\mathrm{v}}$ \\
& for "revap" to occur (mm) & & \\
\hline
\end{tabular}

Note: the superscripts " $r$ " and " $v$ " in the column of optimized value indicate the percent changes based on initial values and replaced parameter values, respectively.
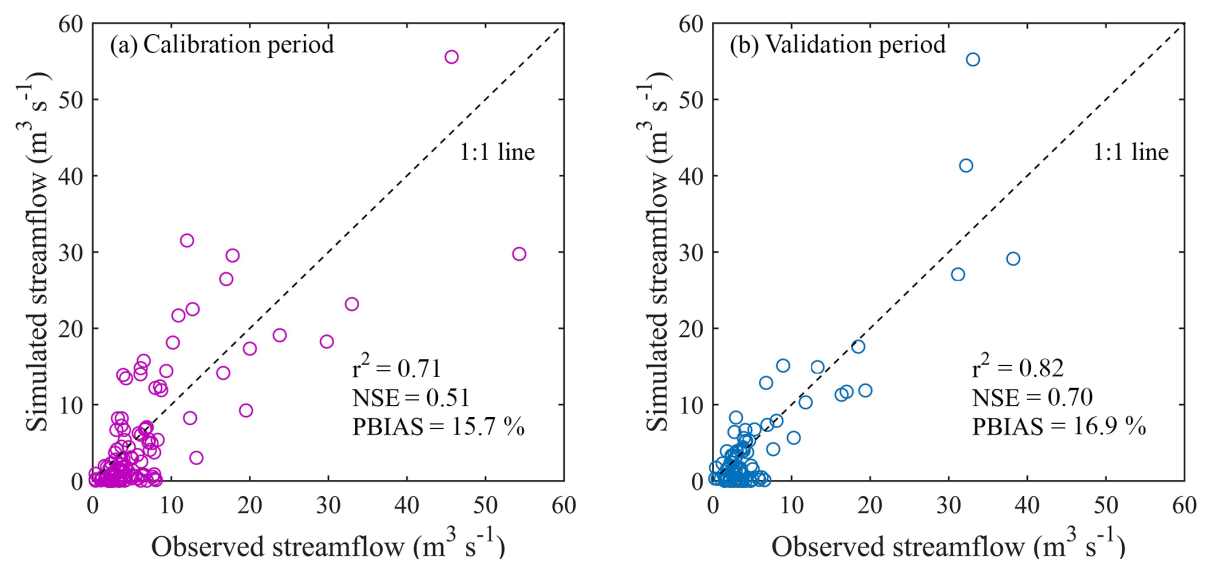

Figure 3. Model performance for the (a) 10-year (1983-1992) calibration period and the (b) 8-year (1993-2000) validation period.

occurred in the spring and winter, during which time little discharge occurs in the watershed. Thus, the model performed poorly during the dry period. Nonetheless, both visual comparison and numerical evaluation indicated that the overall model performance was acceptable for simulating the hydrological processes in the Yanhe Basin.

\subsection{Land use changes in the Yanhe Basin from 1990 to 2010}

Cropland, woodland, and grassland were the primary land use types in the Yanhe Basin, and rapid land use change occurred from 1990 to 2010 (Table 2). A downward trend was observed in cropland, which declined from $40.2 \%$ of the basin area in 1990 to $17.6 \%$ in 2010, whereas upward trends were observed in both grassland and woodland, although these upward trends differed from each other. Grassland slowly increased from 44.7 to $45.3 \%$ between 1990 and 2000 , followed by a rapid increase from 45.3 to $55.1 \%$ between 2000 and 2010. Woodland exhibited an increase of
$73.9 \%$ from 1990 to 2000 , followed by a smaller increase of $7.8 \%$ from 2000 to 2010 . To identify the details of the land use conversion patterns, we explored the mutual conversion among three major land use types: cropland, grassland, and woodland (Table 3). The conversion of cropland to other land use types was observed in the periods of 1990-2000 and 2000-2010, whereas the conversions of grassland or woodland to other land use types were only evident from 1990 to 2000. The cropland area decreased dramatically from 1990 to 2010 primarily due to conversion to woodland or grassland, with conversion percentages of 16.7 and $39.5 \%$, respectively, from 1990 to 2000 and of 6.4 and $33.2 \%$, respectively, from 2000 to 2010. As shown in Fig. 4, the conversions mostly occurred in the central and northwestern parts of the basin from 1990 to 2000 and were scattered from 2000 to 2010. We also examined the land use conversions over the 20-year periods (1990 to 2010) and found that 19.6 and $54.5 \%$ of cropland were transformed to woodland and grassland, respectively, indicating evident LULC change due to the implementation of the GFGP policy in the basin (Table 3). Al- 
Table 2. Land use changes in the Yanhe Basin from 1990 to 2010.

\begin{tabular}{|c|c|c|c|c|c|c|c|c|c|c|c|c|}
\hline & \multicolumn{2}{|c|}{ Cropland } & \multicolumn{2}{|c|}{ Grassland } & \multicolumn{2}{|c|}{ Woodland } & \multicolumn{2}{|c|}{ Residential land } & \multicolumn{2}{|c|}{ Water } & \multicolumn{2}{|c|}{ Barren land } \\
\hline & Area $\left(\mathrm{km}^{2}\right)$ & Pct. (\%) & Area $\left(\mathrm{km}^{2}\right)$ & Pct. (\%) & Area $\left(\mathrm{km}^{2}\right)$ & Pct. (\%) & Area $\left(\mathrm{km}^{2}\right)$ & Pct. (\%) & Area $\left(\mathrm{km}^{2}\right)$ & Pct. (\%) & Area $\left(\mathrm{km}^{2}\right)$ & Pct. (\%) \\
\hline 1990 & 3051.2 & 40.2 & 3390.4 & 44.7 & 1059.6 & 13.9 & 21.4 & 0.28 & 65.4 & 0.86 & 3.1 & 0.040 \\
\hline 2000 & 2246.4 & 29.6 & 3436.3 & 45.3 & 1842.4 & 24.3 & 43.9 & 0.58 & 17.2 & 0.23 & 0.7 & 0.009 \\
\hline 2010 & 1338.3 & 17.6 & 4178.7 & 55.1 & 1986.3 & 26.2 & 66.4 & 0.87 & 16.6 & 0.22 & 0.5 & 0.006 \\
\hline
\end{tabular}

Note: "Pct." stands for the "percentage"; similarly hereinafter.

though the percentages of grassland and woodland increased, $20.1 \%$ of grassland and $19.5 \%$ of woodland were converted into cropland from 1990 to 2000 . Additionally, mutual conversions were observed between grassland and other land use types, but the total area of grassland changed only slightly from 1990 to 2000 . For example, $1204.6 \mathrm{~km}^{2}$ of cropland and $281.5 \mathrm{~km}^{2}$ woodland were converted into grassland, whereas $762.3 \mathrm{~km}^{2}$ and $683.2 \mathrm{~km}^{2}$ of grassland were transformed to woodland and cropland, respectively, in the same period, resulting in a small net change (Table 3). Additionally, despite the increase in woodland from 1990 to $2010,12.6$ and $31.1 \%$ of the woodland from 1990 were converted into cropland and grassland, respectively, with much of this conversion occurring in the southern part of the basin.

\subsection{Water balance components under different land use types}

To further analyze the quantitative impacts of LULC changes on the hydrological cycle, the main hydrological components of individual land use types were assessed via model simulation. The analysis results indicated that the water balance varied among different land use types in the basin (Fig. 5). The overland surface runoff per unit area from residential land was the largest, with an average value of $58.9 \mathrm{~mm}$, followed by that from cropland and grassland at 19.2 and $9.3 \mathrm{~mm}$, respectively. Woodland had the lowest surface runoff of $3.7 \mathrm{~mm}$, which was approximately $80.7 \%$ lower than that of cropland and $62.2 \%$ lower than that of grassland (Fig. 5a). The water yield from individual land use types had trends similar to those of surface runoff. These results implied that the conversions of cropland and grassland to woodland reduced runoff and streamflow at the regional scale. In contrast, the ET of woodland areas was the highest, followed by that of grassland, cropland, and residential land. The soil water of all land use types except residential land exhibited a trend opposite that of ET (cropland > grassland > woodland); woodland areas used more soil water for ET and generated less runoff and streamflow. Figure $5 \mathrm{~b}$ showed the total water volumes for the different land use types in the basin. The highest volumes of surface runoff and water yield were associated with cropland because of its large water volume per unit area and large total area in the basin. Grassland had the largest soil water storage and ET in the basin. The surface runoff, water yield, soil water, and ET of woodland were the lowest among different land use types, except for residential land, due to the small total area of woodland in 1990.

\subsection{Hydrological impacts of historical land use changes}

The impacts of land use changes were simulated by applying the model to three land use scenarios (LU1990, LU2000, and LU2010) with the same climate forcing data (from 1986 to 2015). The simulated streamflow at the outlet of the Yanhe Basin exhibited a downward trend with land use change from 1990 to 2010, and the magnitude of the reduction under LU2010 was larger than that under LU2000 (Fig. 6a). Further analysis showed that relatively large responses mainly occurred from May to September (Fig. 6b). Table 4 presented the simulated average annual components of the water balance in the Yanhe Basin. A decreasing trend was observed in surface runoff at the basin scale as land use changes occurred from 1990 to 2010, with a decrease of $16.6 \%$ under LU2000 and $29 \%$ under LU2010. Land use changes had minor effects on subsurface flow, with a slight increase of $1.8 \%$ under LU2000 and of $2.7 \%$ under LU2010 relative to flow under LU1990. Similar to subsurface flow, ET displayed a weak increasing trend in the basin due to land use changes. The water yield in the basin under LU2000 and LU2010 changed in a similar manner as surface runoff, with decreases of 5.6 and $9.9 \%$, respectively, relative to water yield of LU1990. The soil water decreased by $11 \%$ from 1990 to 2010, with a rapid decrease from 1990 to 2000 and a slow decrease thereafter.

The spatial distributions of the main hydrological components at the HRU scale were shown in Fig. 7. The central part of the basin produced high surface runoff, whereas the most western portion and the southern edge of the basin had little runoff (Fig. 7a and e). Additionally, the decrease in surface runoff from 1990 to 2010 was concentrated in the middle part of the basin. To further understand the hydrological changes associated with land use change, we analyzed the long-term (30-year) average total water volumes of the main hydrological components (Fig. 8). The results showed that decreases in total surface runoff mainly occurred in cropland areas because of their decreased area. The associated decreased percentages were $26.8 \%$ under LU2000 and $57.3 \%$ under LU2010 relative to the surface runoff of LU1990 (Fig. 8a). Although the total surface runoff generated in grassland and woodland areas increased from LU1990 to LU2010, the to- 

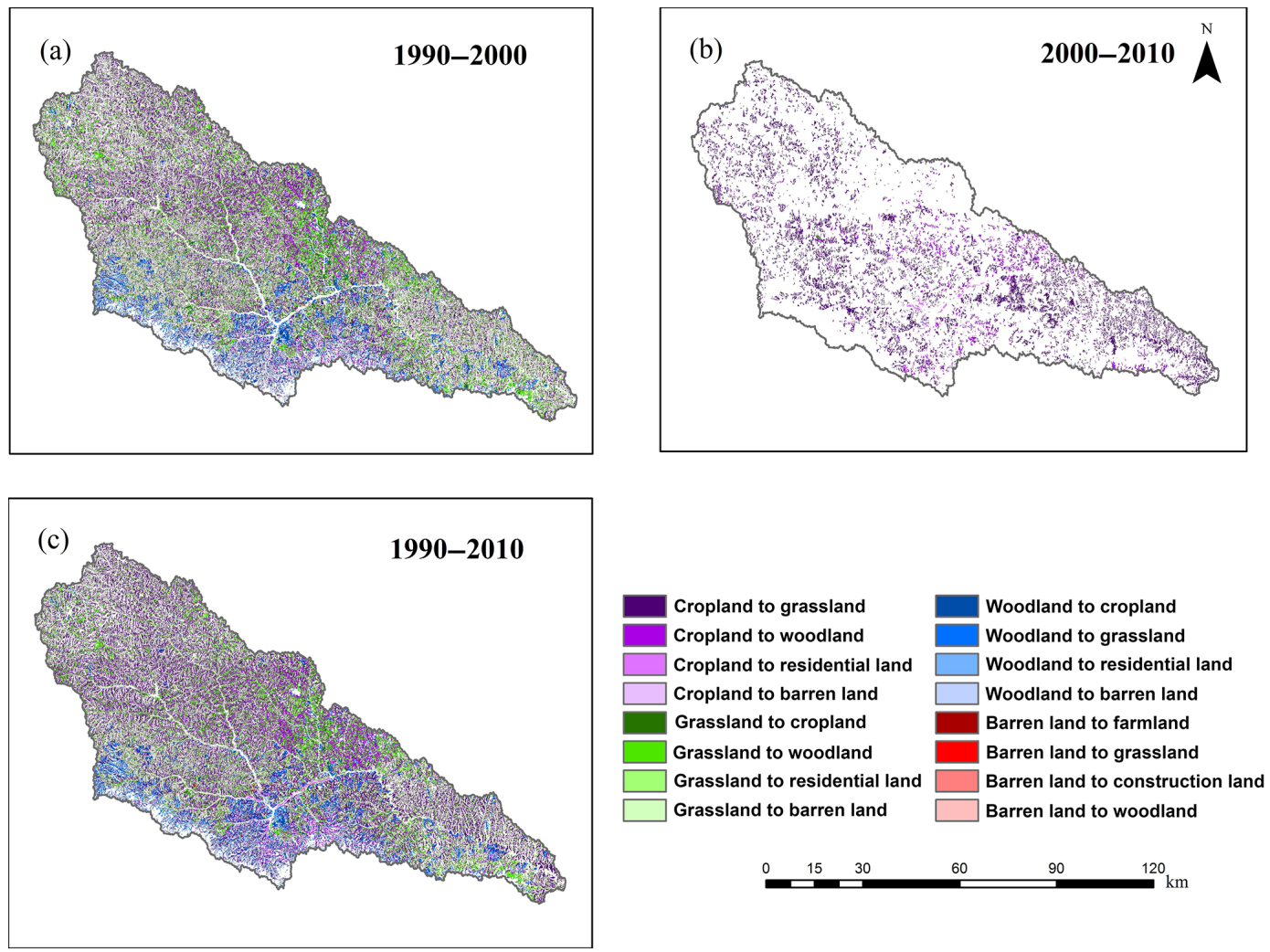

Figure 4. Land use changes from 1990 to 2010 in the Yanhe Basin.
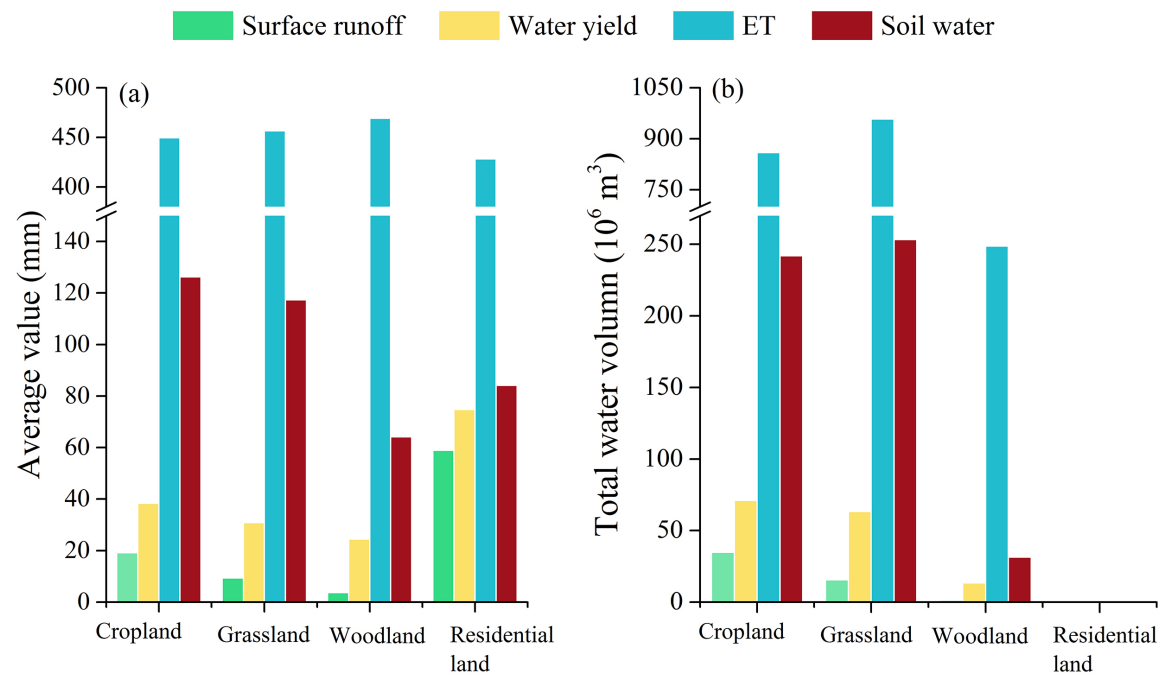

Figure 5. Calculated (a) unit area and (b) total annual hydrological components for the 18-year simulation period (1983-2000) for different land use types in the Yanhe Basin.

tal magnitude of these increases could not compensate for the decrease associated with cropland. Thus, the total surface runoff of the basin decreased. The water yield displayed a trend similar to that of surface runoff from LU1990 to LU2010 (Fig. 7b and f) - the total water yield decreased by
$60.9 \%$ in cropland areas and increased by 18.8 and $136.4 \%$ in grassland and woodland, respectively. These changes were due to the dramatic conversion of cropland to grassland and woodland between LU1990 and LU2010 (Fig. 8b). Similar to the spatiotemporal trends in water yield, ET increased un- 
Table 3. Primary patterns of land use change in the Yanhe Basin from 1990 to 2010.

\begin{tabular}{lrr|rr|rr}
\hline & \multicolumn{2}{c|}{$1990-2000$} & $2000-2010$ & \multicolumn{2}{r}{$1990-2010$} \\
\cline { 2 - 6 } & Area $\left(\mathrm{km}^{2}\right)$ & Pct. (\%) & Area $\left(\mathrm{km}^{2}\right)$ & Pct. (\%) & Area $\left(\mathrm{km}^{2}\right)$ & Pct. (\%) \\
\hline Cropland to woodland & 509.2 & 16.7 & 143.6 & 6.4 & 598.5 & 19.6 \\
Cropland to grassland & 1204.6 & 39.5 & 745.4 & 33.2 & 1661.8 & 54.5 \\
Cropland to residential land & 15.9 & 0.5 & 20.7 & 0.9 & 28.5 & 0.9 \\
Cropland to barren land & 0.3 & 0.0 & 0.0 & 0.0 & 0.1 & 0.0 \\
Grassland to woodland & 762.3 & 22.5 & 0.6 & 0.0 & 796.7 & 23.5 \\
Grassland to cropland & 683.1 & 20.1 & 1.5 & 0.0 & 410.4 & 12.1 \\
Grassland to residential land & 7.1 & 0.2 & 0.6 & 0.0 & 10.4 & 0.3 \\
Grassland to barren land & 0.4 & 0.0 & 0.0 & 0.0 & 0.3 & 0.0 \\
Woodland to cropland & 206.5 & 19.5 & 0.0 & 0.0 & 133.8 & 12.6 \\
Woodland to grassland & 281.5 & 26.6 & 0.0 & 0.0 & 330.1 & 31.1 \\
Woodland to residential land & 5.2 & 0.5 & 0.5 & 0.0 & 9.4 & 0.9 \\
Woodland to barren land & 0.0 & 0.0 & 0.0 & 0.0 & 0.0 & 0.0 \\
Barren land to woodland & 0.2 & 7.4 & 0.0 & 0.0 & 0.2 & 7.4 \\
Barren land to grassland & 0.8 & 25.9 & 0.0 & 0 & 1.0 & 31.7 \\
Barren land to cropland & 2.0 & 65.1 & 0.0 & 0.0 & 1.7 & 54.6 \\
Barren land to residential land & 0.0 & 0.0 & 0.0 & 0.0 & 0.2 & 6.4 \\
\hline
\end{tabular}
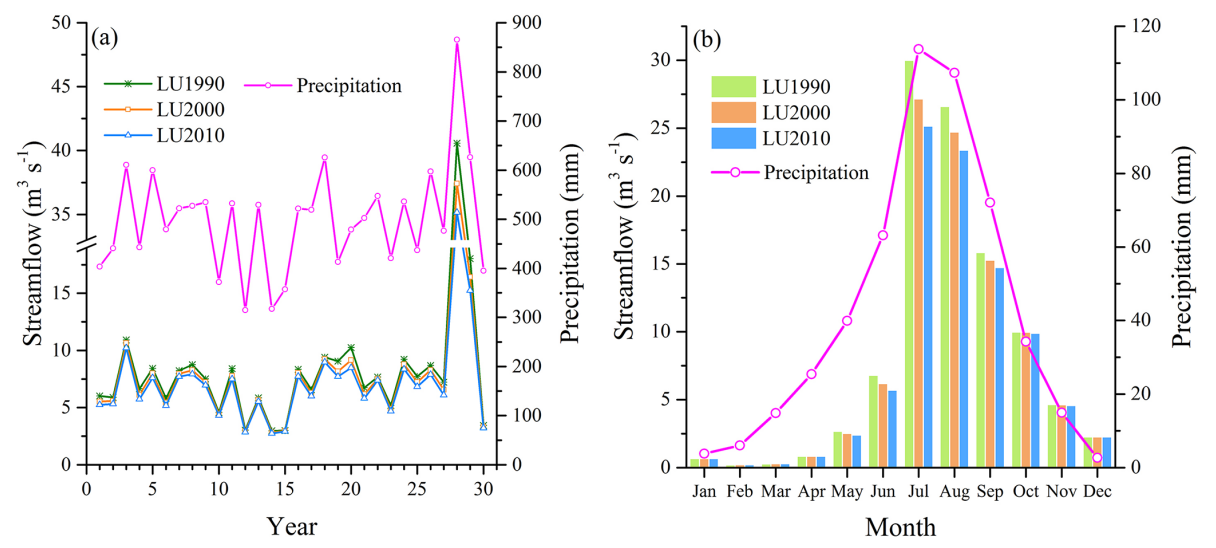

Figure 6. (a) Simulated annual streamflow and (b) simulated multi-year average monthly streamflow (the data were averaged from 1986 to 2015) at the outlet of the Yanhe Basin under different land use conditions.

der LU2010 relative to LU1990 (Fig. 7c and g), whereas it decreased by $58.7 \%$ in cropland and increased by 21.4 and $124.0 \%$ in grassland and woodland, respectively, from LU1990 to LU2010 (Fig. 8c). In terms of the spatial distribution of soil water, an evident decrease occurred under LU2010, with the highest decrease occurring in the northcentral part of the region (Fig. $7 \mathrm{~d}$ and h). Although the total soil water increased in woodland with land use change, the total soil water was lowest in woodland under all three land use scenarios (Fig. 8d).

\subsection{Potential impacts of hypothetical SLC}

The potential hydrological effects of SLC were projected by inputting four land conversion scenarios that were reconstructed based on the LU2010 baseline (Table 5). The changes in land use in $\mathrm{S} 1$ led to the conversion of $131.6 \mathrm{~km}^{2}$ cropland with slope $>25^{\circ}$ to grassland, which resulted in slight decreases in surface runoff, water yield, and soil water, whereas minor increases were found in subsurface flow and ET. With the same acreage of cropland to woodland conversion in S2, the induced hydrological effects were similar to those in S1, whereas the differences between S2 and the baseline were larger in magnitude than those between $\mathrm{S} 1$ and the baseline. When the land conversion was extended to cropland with slope $\geq 15^{\circ}$, the trends of hydrological change were strengthened. For example, in S3, grassland increased by 23.9 and $15.3 \%$ on land surfaces with slopes of 15-25 and $>25^{\circ}$, respectively, resulting in 12.4 and $2.7 \%$ decreases in surface runoff and water yield, respectively, relative to the baseline. Conversely, subsurface flow and ET increased slightly by 2.2 and $0.2 \%$, respectively. Although soil wa- 
Table 4. Simulated average annual values of hydrological components in the Yanhe Basin under different land use conditions.

\begin{tabular}{cccccc}
\hline & $\begin{array}{c}\text { Surface } \\
\text { runoff } \\
(\mathrm{mm})\end{array}$ & $\begin{array}{c}\text { Subsurface } \\
\text { flow } \\
(\mathrm{mm})\end{array}$ & ET & $\begin{array}{c}\text { Water } \\
\text { yield } \\
(\mathrm{mm})\end{array}$ & $\begin{array}{c}\text { Soil } \\
\text { water } \\
(\mathrm{mm})\end{array}$ \\
\hline LU1990 & 15.1 & 22.2 & 461.8 & 37.3 & 123.0 \\
LU2000 & 12.6 & 22.6 & 464.5 & 35.2 & 113.1 \\
LU2010 & 10.7 & 22.8 & 466.5 & 33.6 & 109.5 \\
\hline
\end{tabular}

ter consistently exhibited a negative response, the decreases were small. When the same area of cropland with slope $\geq 15^{\circ}$ was converted to woodland in S4, the surface runoff and water yield decreased by 17.1 and $6.4 \%$ relative to the baseline, while subsurface flow and ET increased by 3.9 and $0.3 \%$, respectively. Soil water notably changed in S4, decreasing by $6.4 \%$ relative to the baseline soil water. Figure 9 illustrated the spatial response of soil water to land use conversion scenarios relative to the baseline of 2010 . The soil water decrease in S4 mainly occurred along the southern edge of the basin and the north-central part of the basin, which were areas of high elevation and high slope gradient (Fig. 9d).

\section{Discussion}

In this study, the performance of the SWAT model was evaluated using monthly streamflow data from the Ganguyi hydrological station. Although the calibrated model slightly underestimated streamflow in the dry period in both the calibration and validation periods, the three statistical indexes (NSE, PBIAS, $r^{2}$ ) indicated that the modeling accuracy was acceptable. The potential reasons for the underestimation can be categorized as "measurement quality" and "model behavior" reasons. Measurement quality refers to missing precipitation data or streamflow measuring error. The study area lies in the hilly-gullied loess region, and the complex and rugged terrain results in highly variable precipitation and difficulties in spatially estimating the precipitation (Cao et al., 2006). Additionally, this region has a limited number of meteorological and hydrological stations. In this study, five meteorological stations were involved; however, only three stations are located inside the basin, with the remaining two occurring outside the basin (Fig. 1). It has been reported that the accuracy of streamflow prediction mainly depends upon the precipitation gage numbers and their locations (Cao et al., 2006; Mul et al., 2009). Thus, the insufficient precipitation records and the distances among the meteorological stations resulted in poor streamflow simulation. Model behavior refers to model limitations such as the inadequate representation of the physical mechanism of hydrological processes. For example, SWAT uses total daily precipitation and does not consider rainfall intensity within a day; thus, it can underestimate streamflow for some precipitation events (Qiu et

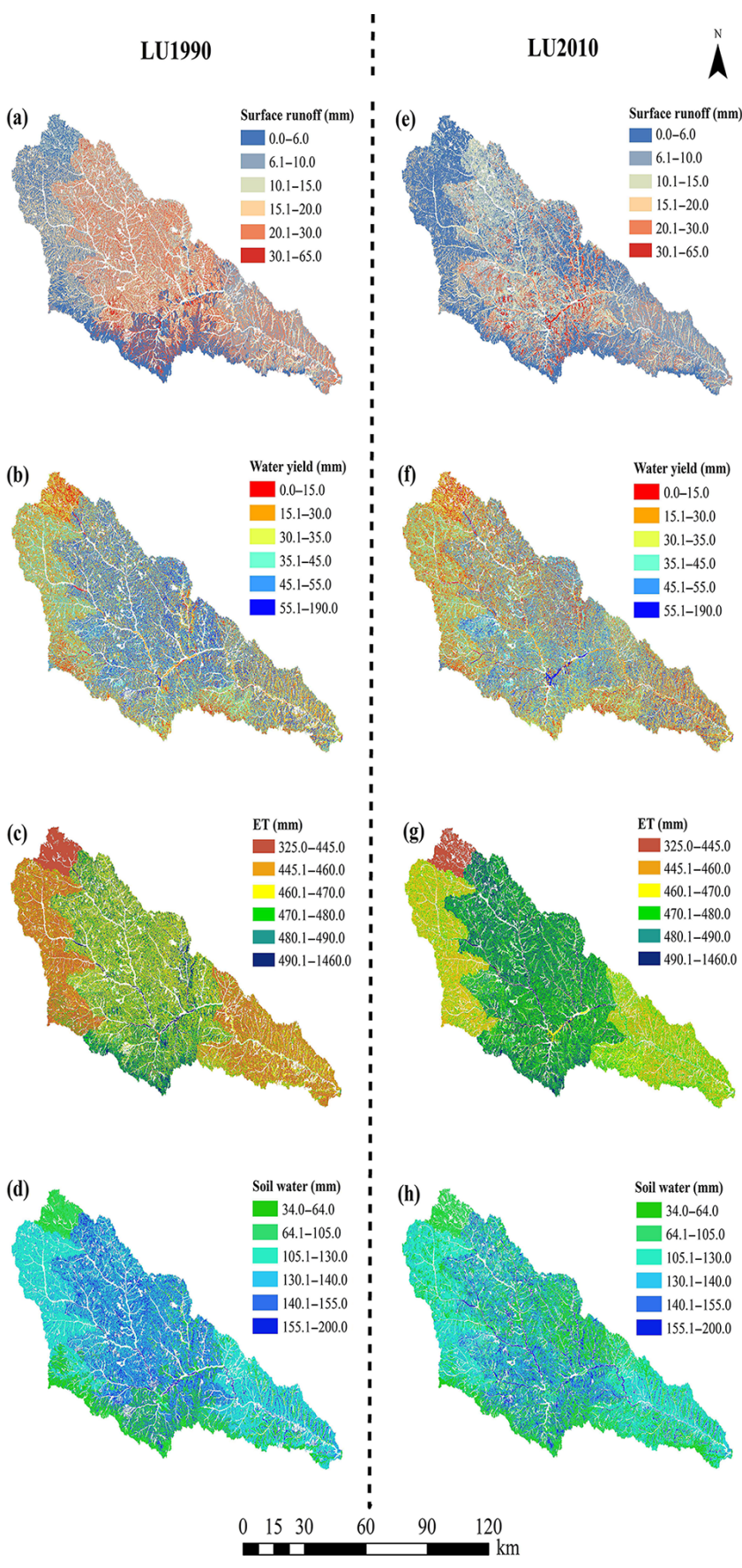

Figure 7. Simulated spatial distribution of surface runoff, water yield, ET, and soil water under land use change between 1990 (ad) and 2010 (e-h).

al., 2012). Another example is the use of runoff curve number to simulate the surface runoff behavior. This approach does not account for saturation excess runoff or contributions from variable source areas (Garen and Moore, 2005; Easton et al., 2008). Although the simulation results in our research met the calibration criteria, the model performance can be 
Table 5. Slope characteristics of each land use type at baseline and under different slope land conversion scenarios (unit: $\mathrm{km}^{2}$ ).

\begin{tabular}{rrrrrrr}
\hline & & Cropland & Woodland & Grassland & $\begin{array}{r}\text { Residential } \\
\text { land }\end{array}$ & $\begin{array}{r}\text { Barren } \\
\text { land }\end{array}$ \\
\hline BS & $<15^{\circ}$ & 814.3 & 761.2 & 1677.7 & 52.5 & 0.3 \\
& $15-25^{\circ}$ & 392.7 & 808.4 & 1640.8 & 10.8 & 0.1 \\
& $>25^{\circ}$ & 131.6 & 417.3 & 860.9 & 3.2 & 0.0 \\
& $<15^{\circ}$ & - & - & - & - & - \\
\hline S1 & $15-25^{\circ}$ & - & - & - & - & - \\
& $>25^{\circ}$ & 0 & 417.3 & 992.5 & 3.2 & 0.0 \\
& $<15^{\circ}$ & - & - & - & - & - \\
\hline S2 & $15-25^{\circ}$ & - & - & - & - & - \\
& $>25^{\circ}$ & 0 & 548.9 & 860.9 & 3.2 & 0.0 \\
& $<15^{\circ}$ & - & - & - & - & - \\
\hline S3 & $15-25^{\circ}$ & 0 & 808.4 & 2033.5 & 10.8 & 0.1 \\
& $>25^{\circ}$ & 0 & 417.3 & 992.5 & 3.2 & 0.0 \\
& $<15^{\circ}$ & - & - & - & - & - \\
\hline S4 & $15-25^{\circ}$ & 0 & 1201.0 & 1640.8 & 10.8 & 0.1 \\
& $>25^{\circ}$ & 0 & 548.9 & 860.9 & 3.2 & 0.0 \\
\hline
\end{tabular}

Note: “-” indicates the same value as that of BS (LU2010).

\section{LU1990 LU2000 —LU2010}
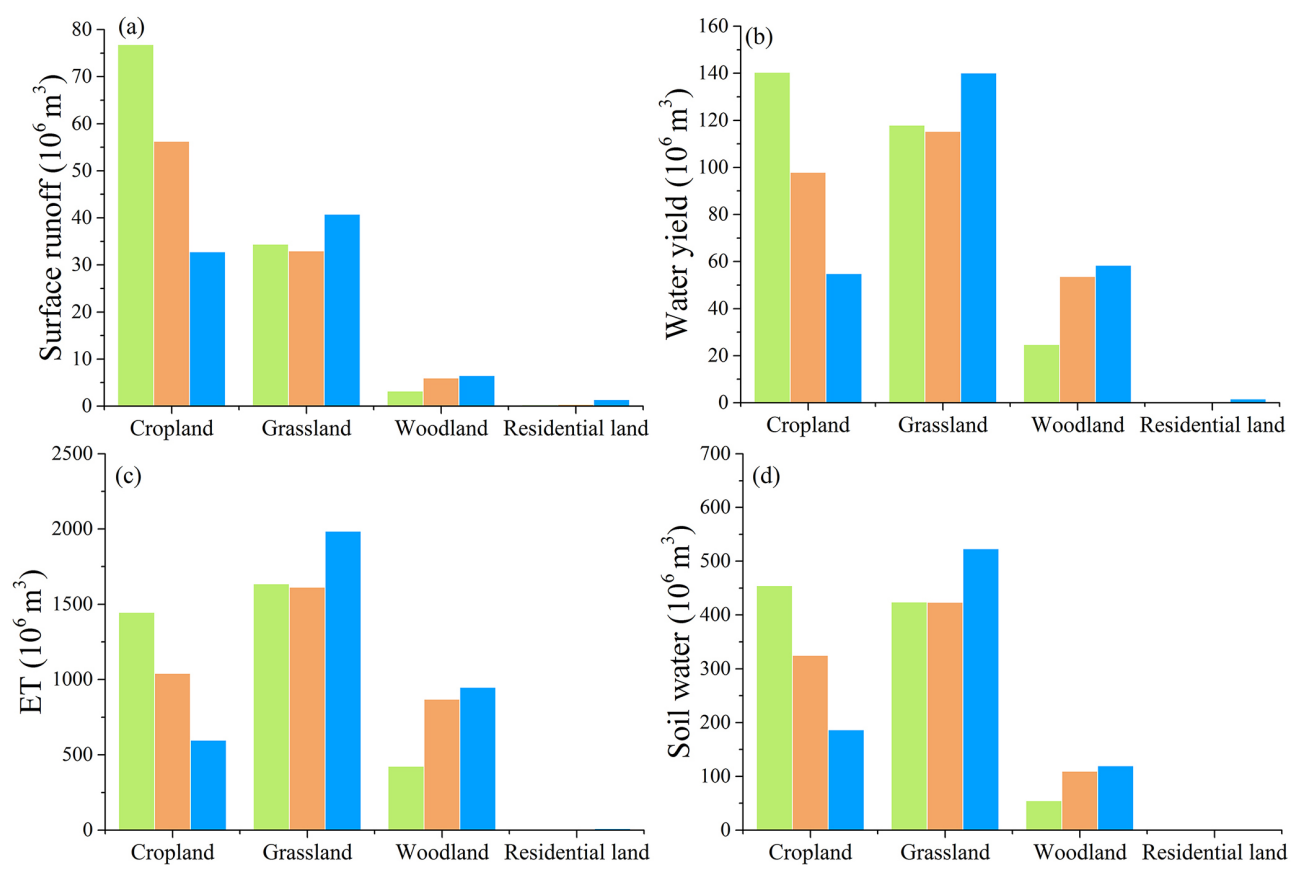

Figure 8. Calculated average annual total water volume under different land use scenarios.

improved if precipitation data from additional gages become available in the basin.

Cropland, grassland, and woodland were the primary land use types in the Yanhe Basin, and the sum of their area accounted for more than $95 \%$ of the total area during the period under study. To investigate the effects of land use change and management practices on the water balance, three land use scenarios were assessed using the SWAT model. The contributions of individual land use types to basin hydrology differed. Cropland had the highest soil water which can be partly attributed to its topography. The cropland area was mainly distributed in the bottom region of the valley and 
(a)

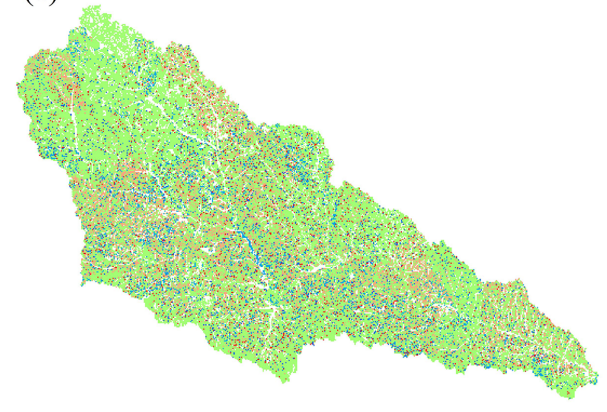

(c)

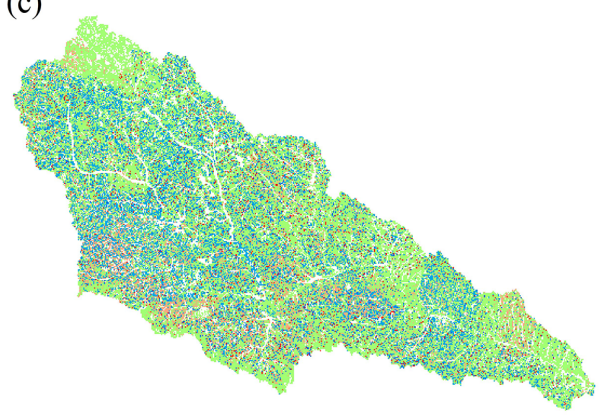

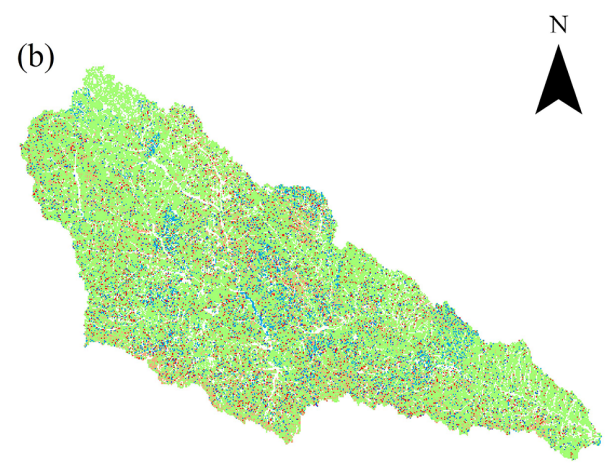

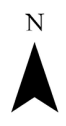

(d)

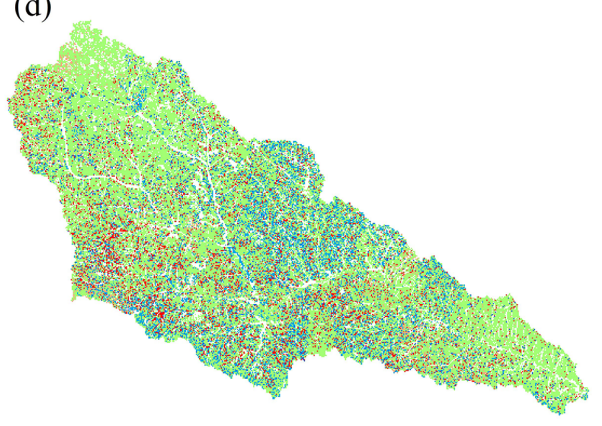

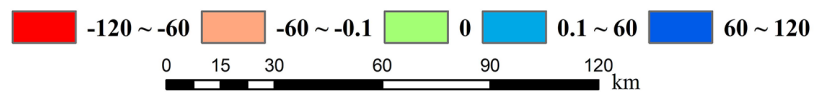

Figure 9. Calculated soil water difference between the baseline scenario and (a) S1, (b) S2, (c) S3, and (d) S4 .

Table 6. Simulated average annual values of hydrological components under different scenarios of slope land conversion.

\begin{tabular}{lrrrrr}
\hline & $\begin{array}{r}\text { Surface } \\
\text { runoff } \\
(\mathrm{mm})\end{array}$ & $\begin{array}{r}\text { Subsurface } \\
\text { flow } \\
(\mathrm{mm})\end{array}$ & ET & $\begin{array}{r}\text { Water } \\
\text { yield } \\
(\mathrm{mm})\end{array}$ & $\begin{array}{r}\text { Soil } \\
\text { water } \\
(\mathrm{mm})\end{array}$ \\
\hline S1 & 10.4 & 22.9 & 466.8 & 33.3 & 109.0 \\
S2 & 10.3 & 23.0 & 466.9 & 33.2 & 107.7 \\
S3 & 9.37 & 23.3 & 467.6 & 32.7 & 107.5 \\
S4 & 8.87 & 23.7 & 467.8 & 32.6 & 102.5 \\
\hline
\end{tabular}

on land with a gentle slope. The valley bottom generally receives more water flow from the hillslope and has lower temperatures than higher regions, resulting in more soil water (Wang et al., 2012). Furthermore, land with a gentle slope has higher soil water retention ability than does land with a steep slope (Panagopoulos et al., 2011). In addition, cropland had lower ET per unit area than did the other land use types. In contrast, grassland had lower soil water, which can be attributed to its higher soil water loss through ET. Wang et al. (2012) reported that grass cover types cannot protect the soil surface from solar radiation, leading to greater water loss via direct evaporation. Woodland and, to a lesser extent, grassland areas were generally associated with lower surface runoff and water yield in the basin. This result is consistent with those of previous studies demonstrating that woodland areas capture more rainfall and uptake more water than do other land use types (e.g., cropland and grassland) (Jian et al., 2015; Wang et al., 2012), resulting in a lower runoff and water discharge (Wang et al., 2013; Duan et al., 2016). Qiao et al. (2017) reported that the reduced runoff in areas with woody plants relative to grassland areas is associated with a shift in runoff generation mechanisms from saturation excess overland flow to infiltration excess overland flow. Such type of shift might also have contributed to the reduced runoff in woodland areas observed in the present study. Additionally, compared with other vegetation types, woodland areas might lose more water through ET. This pattern was evident from the change in soil water, with less soil water in woodland than in other areas under the same precipitation amount. Less soil water was observed in woodland because forests in the Yanhe Basin generally grow on landforms with high slopes; our analysis indicated that more than $62 \%$ of woodland was 
located on slopes $\geq 15^{\circ}$ (Table 5). Steeper slopes generally retain less soil water due to low infiltration and rapid surface drainage (Famiglietti et al., 1998). Thus, a large amount of precipitation was associated with forest growth and ET rather than discharge out of the basin as surface runoff and streamflow. Such water patterns prevent water loss but at the expense of reduced soil water in the region.

After the implementation of the GFGP, the area of cropland decreased continuously because it was transformed into grassland and woodland from 1990 to 2010, and conversions among land use types were the main forms of land use change in the Yanhe Basin. These results are consistent with previous findings regarding trends in land use change on the Loess Plateau (Li et al., 2016). We compared monthly and annual average streamflow under three land use scenarios, and the results showed that the decreased average monthly streamflow in the rainy season is the primary mechanism for the decrease in annual average streamflow in the basin. In addition, we found that the decrease in surface runoff was the main reason for the streamflow decrease in the basin, and our quantitative evaluation suggested that surface runoff decreased by $29.1 \%$ from 1990 to 2010 due to land use change. A similar conclusion was drawn by Farley et al. (2005), who studied 26 watersheds globally to assess the hydrological effect of afforestation and found that annual runoff was reduced by $31-44 \%$ on average. Notably, the average annual volume of soil water presented an evident decrease under the 2010 land use scenario. This trend might be due to two interrelated reasons. First, the area of cropland decreased dramatically in 2010 , and cropland was characterized by the highest soil water volume per unit area relative to other land use types (Fig. 5a), leading to the large decrease in soil water. Second, a certain proportion of cropland was converted to grassland and woodland, which had the lowest soil water per unit area; thus, the soil water decreased due to the cropland area reduction, and this decrease could not be offset by increases in total soil water in grassland and woodland areas (Fig. 8). Although the area of woodland peaked in 2010, the total soil water in woodland areas increased only slightly. The main reason for this phenomenon might be that more water was consumed by woodland than cropland and grassland. Additionally, cropland areas with high slopes were converted to woodland after the GFGP was implemented (Zhou et al., 2012), and areas with steep slopes have lower soil water retention potentials than do areas with gentle slopes (Pachepsky et al., 2001). Thus, topographical factors also played important roles in the spatial heterogeneity of the water balance (Qiu et al., 2001; Bi et al., 2008).

Four future SLC scenarios were proposed to demonstrate the hydrological effects of land use changes. Increases in grassland or woodland cover due to the land conversion of cropland with slopes $\geq 15$ or $>25^{\circ}$ had negative effects on surface runoff, water yield, and soil water, and positive effects on subsurface flow and ET. We found that the magnitudes of the hydrological effects of the conversion of sloping cropland to woodland were greater than those associated with the conversion of sloping cropland to grassland. This result suggests that the expansion of woodland could reduce runoff generation and drainage because of overland flow retention and intensification of ET in this region. However, the revegetated sloping land was prone to reduced soil water due to its steep slope. Some studies have reported that revegetation can cause soil water shortages in both the near-surface soil and deep soil layers (Farley et al., 2005; Jian et al., 2015), likely resulting in soil desiccation (Wang et al., 2011; Fu et al., 2012). Therefore, watershed management should consider all water balance components (Duan et al., 2016), and vegetative structure and management measures should be optimized to improve ecohydrological functions and promote watershed sustainability.

\section{Conclusions}

In this study, we found that cropland, grassland, and woodland were the dominant land use types in the Yanhe Basin, and land use conversion among these types occurred since 1990 due to the implementation of the GFGP. The decrease in cropland led to an increase in grassland and woodland. The impacts of LULC changes on the water balance components were assessed quantitatively using the SWAT model, three periods of land use maps, and four hypothetical SLC scenarios based on the GFGP policy on the Loess Plateau. Our analysis showed that cropland was associated with the highest surface runoff and water discharge per unit area, followed by grassland and woodland. These differences can partly explain the relationships between hydrological characteristics and land use change at the basin scale. Surface runoff and water yield decreased due to land use changes from 1990 to 2010 while subsurface flow and ET increased. Consequently, soil water decreased between 2000 and 2010. By adopting four cropland land conversion scenarios, we found that the function of reducing surface runoff was more effective when cropland with slopes $\geq 15^{\circ}$ was converted into grassland or woodland than when areas with slopes $>25^{\circ}$ were converted. Furthermore, afforestation had greater hydrological effects than grass planting on sloping land. Notably, surface runoff and soil water decreased and ET increased. Overall, this study provides useful information for land use planning and soil and water conservation on the Loess Plateau. Further studies are required to investigate the optimization of the vegetative structure and the avoidance of undesired hydrological effects.

Data availability. The climate and streamflow data used in this study are available for non-commercial use upon request from the corresponding author (yipingwu@xjtu.edu.cn). The DEM data of study area are available at the National Geomatics Center of China (http://www.ngcc.cn/). The other underlying research data 
and modeling results are available online at https://pan.baidu.com/ s/1eSariG6.

Competing interests. The authors declare that they have no conflict of interest.

Special issue statement. This article is part of the special issue "Coupled terrestrial-aquatic approaches to watershed-scale water resource sustainability". It is not associated with a conference.

Acknowledgements. This work was supported by the Thousand Youth Talent Program of China (122990901606), the National Natural Science Foundation of China (41301223), the China Postdoctoral Science Foundation Grant (2016M592777), and the State Key Research and Development Project (2016YFC0402208, 2016YFC0401903). We appreciate the constructive comments from the two anonymous reviewers. We also thank the HPCC platform in $\mathrm{Xi}$ 'an Jiaotong University for computing equipment and computer maintenance.

Edited by: Zhenyao Shen

Reviewed by: two anonymous referees

\section{References}

Alkama, R., Marchand, L., Ribes, A., and Decharme, B.: Detection of global runoff changes: results from observations and CMIP5 experiments, Hydrol. Earth Syst. Sci., 17, 2967-2979, https://doi.org/10.5194/hess-17-2967-2013, 2013.

Arnold, J. G., Srinivasan, R., Muttiah, R. S., and Williams, J. R.: Large area hydrologic modeling and assessment - Part 1: Model development, J. Am. Water Resour. As., 34, 73-89, https://doi.org/10.1111/j.1752-1688.1998.tb05961.x, 1998.

Arnold, J. G., Moriasi, D. N., Gassman, P. W., Abbaspour, K. C., White, M. J., Srinivasan, R., Santhi, C., Harmel, R. D., van Griensven, A., Van Liew, M. W., Kannan, N., and Jha, M. K.: SWAT: Model use, calibration, and validation, T. ASABE, 55, 1491-1508, https://doi.org/10.13031/2013.42256, 2012.

Bari, M. and Smettem, K. R. J.: Modelling monthly runoff generation processes following land use changes: groundwatersurface runoff interactions, Hydrol. Earth Syst. Sci., 8, 903-922, https://doi.org/10.5194/hess-8-903-2004, 2004.

Bi, H., Zhang, J., Zhu, J., Lin, L., Guo, C., Ren, Y., Yun, L., and Ma, N.: Spatial dynamics of soil moisture in a complex terrain in the semi-arid Loess Plateau region, China, J. Am. Water Resour. As., 44, 1121-1131, https://doi.org/10.1111/j.17521688.2008.00236.x, 2008.

Blöschl, G., Ardoin-Bardin, S., Bonell, M., Dorninger, M., Goodrich, D., Gutknecht, D., Matamoros, D., Merz, B., Shand, P., and Szolgay, J.: At what scales do climate variability and land cover change impact on flooding and low flows?, Hydrol. Process., 21, 1241-1247, https://doi.org/10.1002/hyp.6669, 2007.

Bosch, D. D., Arnold, J. G., Volk, M., and Allen, P. M.: Simulation of a low-gradient coastal plain watershed us- ing the SWAT landscape model, T. ASABE, 53, 1445-1456, https://doi.org/10.13031/2013.34899, 2010.

Cao, W. Z., Bowden, W. B., Davie, T., and Fenemor, A.: Multivariable and multi-site calibration and validation of SWAT in a large mountainous catchment with high spatial variability, Hydrol. Process., 20, 1057-1073, https://doi.org/10.1002/hyp.5933, 2006.

Chawla, I. and Mujumdar, P. P.: Isolating the impacts of land use and climate change on streamflow, Hydrol. Earth Syst. Sci., 19, 3633-3651, https://doi.org/10.5194/hess-19-3633-2015, 2015.

Chen, H., Shao, M., and Li, Y.: Soil desiccation in the Loess Plateau of China, Geoderma, 143, 91-100, https://doi.org/10.1016/j.geoderma.2007.10.013, 2008.

Chen, L., Huang, Z., Gong, J., Fu, B., and Huang, Y.: The effect of land cover/vegetation on soil water dynamic in the hilly area of the loess plateau, China, Catena, 70, 200-208, https://doi.org/10.1016/j.catena.2006.08.007, 2007.

Chu, H. J., Lin, Y. P., Huang, C. W., Hsu, C. Y., and Chen, H. Y.: Modelling the hydrologic effects of dynamic land-use change using a distributed hydrologic model and a spatial land-use allocation model, Hydrol. Process., 24, 2538-2554, https://doi.org/10.1002/hyp.7667, 2010.

Douglas-Mankin, K. R., Srinivasan, R., and Arnold, J. G.: Soil and water assessment tool (SWAT) model: current developments and applications, T. ASABE, 53, 1423-1431, https://doi.org/10.13031/2013.34915, 2010.

Duan, L. X., Huang, M. B., and Zhang, L. D.: Differences in hydrological responses for different vegetation types on a steep slope on the Loess Plateau, China, J. Hydrol., 537, 356-366, https://doi.org/10.1016/j.jhydrol.2016.03.057, 2016.

Easton, Z. M., Fuka, D. R., Walter, M. T., Cowan, D. M., Schneiderman, E. M., and Steenhuis, T. S.: Re-conceptualizing the soil and water assessment tool (SWAT) model to predict runoff from variable source areas, J. Hydrol., 348, 279-291, https://doi.org/10.1016/j.jhydrol.2007.10.008, 2008.

Famiglietti, J. S., Rudnicki, J. W., and Rodell, M.: Variability in surface moisture content along a hillslope transect: Rattlesnake Hill, Texas, J. Hydrol., 210, 259-281, https://doi.org/10.1016/S00221694(98)00187-5, 1998.

Farley, K. A., Jobbagy, E. G., and Jackson, R. B.: Effects of afforestation on water yield: a global synthesis with implications for policy, Glob. Change Biol., 11, 1565-1576, https://doi.org/10.1111/j.1365-2486.2005.01011.x, 2005.

FAO: World reference base for soil resources: International soil classification system for naming soils and creating legends for soil map. World soil resources reports no. 106, Rome, http://www.fao.org/publications/card/en/c/ 942e424c-85a9-411d-a739-22d5f8b6cc41/ (last access: 16 December 2017), 2014.

Feng, X., Fu, B., Piao, S., Wang, S., Ciais, P., Zeng, Z., Lu, Y., Zeng, Y., Li, Y., Jiang, X., and Wu, B.: Revegetation in China's Loess Plateau is approaching sustainable water resource limits, Nature Climate Change, 6, 1019-1022, https://doi.org/10.1038/nclimate3092, 2016.

Fu, W., Huang, M., Gallichand, J., and Shao, M.: Optimization of plant coverage in relation to water balance in the Loess Plateau of China, Geoderma, 173-174, 134-144, https://doi.org/10.1016/j.geoderma.2011.12.016, 2012. 
Garen, D. C. and Moore, D. S.: Curve number hydrology in water quality modeling: Uses, abuses, and future directions, J. Am. Water Resour. As., 41, 377-388, https://doi.org/10.1111/j.17521688.2005.tb03742.x, 2005.

Gassman, P. W., Sadeghi, A. M., and Srinivasan, R.: Applications of the SWAT model special section: overview and insights, J. Environ. Qual., 43, 1-8, https://doi.org/10.2134/jeq2013.11.0466, 2014.

Guo, Z. T., Ruddiman, W. F., Hao, Q. Z., Wu, H. B., Qiao, Y. S., Zhu, R. X., Peng, S. Z., Wei, J. J., Yuan, B. Y., and Liu, T. S.: Onset of Asian desertification by $22 \mathrm{Myr}$ ago inferred from loess deposits in China, Nature, 416, 159-163, https://doi.org/10.1038/416159a, 2002.

Huang, M. B., Zhang, L., and Gallichand, J.: Runoff responses to afforestation in a watershed of the Loess Plateau, China, Hydrol. Process., 17, 2599-2609, https://doi.org/10.1002/hyp.1281, 2003.

Jian, S. Q., Zhao, C. Y., Fang, S. M., and Yu, K.: Effects of different vegetation restoration on soil water storage and water balance in the Chinese Loess Plateau, Agr. Forest Meteorol., 206, 85-96, https://doi.org/10.1016/j.agrformet.2015.03.009, 2015.

Li, J. J., Li, Z., and Lu, Z. M.: Analysis of spatiotemporal variations in land use on the Loess Plateau of China during 1986-2010, Environ. Earth Sci., 75, 997, https://doi.org/10.1007/s12665-0165807-y, 2016.

Li, Z., Liu, W., Zhang, X., and Zheng, F.: Impacts of land use change and climate variability on hydrology in an agricultural catchment on the Loess Plateau of China, J. Hydrol., 377, 35-42, https://doi.org/10.1016/j.jhydrol.2009.08.007, 2009.

Liang, W., Bai, D., Wang, F. Y., Fu, B. J., Yan, J. P., Wang, S., Yang, Y. T., Long, D., and Feng, M. Q.: Quantifying the impacts of climate change and ecological restoration on streamflow changes based on a Budyko hydrological model in China's Loess Plateau, Water Resour. Res., 51, 6500-6519, https://doi.org/10.1002/2014wr016589, 2015.

Liu, J., Li, S., Ouyang, Z., Tam, C., and Chen, X.: Ecological and socioeconomic effects of China's policies for ecosystem services, P. Natl. Acad. Sci. USA, 105, 9477-9482, https://doi.org/10.1073/pnas.0706436105, 2008a.

Liu, M., Tian, H., Chen, G., Ren, W., Zhang, C., and Liu, J.: Effects of land-use and land-cover change on evapotranspiration and water yield in China during 1900-2000, J. Am. Water Resour. As., 44, 1193-1207, https://doi.org/10.1111/j.17521688.2008.00243.x, 2008b.

Liu, M., Tian, H., Yang, Q., Yang, J., Song, X., Lohrenz, S. E., and Cai, W.-J.: Long-term trends in evapotranspiration and runoff over the drainage basins of the Gulf of Mexico during 1901-2008, Water Resour. Res., 49, 1988-2012, https://doi.org/10.1002/wrcr.20180, 2013.

Liu, Y., Xiao, J., Ju, W., Xu, K., Zhou, Y., and Zhao, Y.: Recent trends in vegetation greenness in China significantly altered annual evapotranspiration and water yield, Environ. Res. Lett., 11, 094010, https://doi.org/10.1088/1748-9326/11/9/094010, 2016.

López-Moreno, J. I., Vicente-Serrano, S. M., Moran-Tejeda, E., Zabalza, J., Lorenzo-Lacruz, J., and García-Ruiz, J. M.: Impact of climate evolution and land use changes on water yield in the ebro basin, Hydrol. Earth Syst. Sci., 15, 311-322, https://doi.org/10.5194/hess-15-311-2011, 2011.
Lørup, J. K., Refsgaard, J. C., and Mazvimavi, D.: Assessing the effect of land use change on catchment runoff by combined use of statistical tests and hydrological modelling: Case studies from Zimbabwe, J. Hydrol., 205, 147-163, https://doi.org/10.1016/S0168-1176(97)00311-9, 1998.

McVicar, T. R., Li, L., Van Niel, T. G., Zhang, L., Li, R., Yang, Q., Zhang, X., Mu, X., Wen, Z., Liu, W., Zhao, Y. A., Liu, Z., and Gao, P.: Developing a decision support tool for China's re-vegetation program: Simulating regional impacts of afforestation on average annual streamflow in the Loess Plateau, Forest Ecol. Manag., 251, 65-81, https://doi.org/10.1016/j.foreco.2007.06.025, 2007.

McVicar, T. R., Van Niel, T. G., Li, L., Wen, Z., Yang, Q., Li, R., and Jiao, F.: Parsimoniously modelling perennial vegetation suitability and identifying priority areas to support China's revegetation program in the Loess Plateau: Matching model complexity to data availability, Forest Ecol. Manag., 259, 1277-1290, https://doi.org/10.1016/j.foreco.2009.05.002, 2010.

Mul, M. L., Savenije, H. H. G., and Uhlenbrook, S.: Spatial rainfall variability and runoff response during an extreme event in a semiarid catchment in the South Pare Mountains, Tanzania, Hydrol. Earth Syst. Sci., 13, 1659-1670, https://doi.org/10.5194/hess-131659-2009, 2009.

Nash, J. E. and Sutcliffe, J. V.: River flow forecasting through conceptual models part I - A discussion of principles, J. Hydrol., 10, 282-290, https://doi.org/10.1016/0022-1694(70)90255-6, 1970.

Neitsch, S. L., Arnold, J. G., Kiniry, J. R., and Williams, J. R.: Soil and water assessment tool theoretical documentation version 2009, Texas Water Resources Institute Technical Report 406 Texas A\&M University System, College Station, Texas, 2011.

Neupane, R. P. and Kumar, S.: Estimating the effects of potential climate and land use changes on hydrologic processes of a large agriculture dominated watershed, J. Hydrol., 529, 418-429, https://doi.org/10.1016/j.jhydrol.2015.07.050, 2015.

Nyeko, M.: Hydrologic modelling of data scarce basin with SWAT model: capabilities andl imitations, Water Resour. Manag., 29, 81-94, https://doi.org/10.1007/s11269-014-0828-3, 2015.

Pachepsky, Y. A., Timlin, D. J., and Rawls, W. J.: Soil water retention as related to topographic variables, Soil Sci. Soc. Am. J., 65, 1787-1795, https://doi.org/10.2136/sssaj2001.1787, 2001.

Panagopoulos, Y., Makropoulos, C., Baltas, E., and Mimikou, M.: SWAT parameterization for the identification of critical diffuse pollution source areas under data limitations, Ecol. Model., 222, 3500-3512, https://doi.org/10.1016/j.ecolmodel.2011.08.008, 2011.

Qiao, L., Zou, C. B., Stebler, E., and Will, R. E.: Woody plant encroachment reduces annual runoff and shifts runoff mechanisms in the tallgrass prairie, USA, Water Resour. Res., 53, 4838-4849, https://doi.org/10.1002/2016WR019951, 2017.

Qiu, L. J., Zheng, F. L., and Yin, R. S.: SWAT-based runoff and sediment simulation in a small watershed, the loessial hilly-gullied region of China: capabilities and challenges, Int. J. Sediment Res., 27, 226-234, https://doi.org/10.1016/S10016279(12)60030-4, 2012.

Qiu, Y., Fu, B. J., Wang, J., and Chen, L. D.: Soil moisture variation in relation to topography and land use in a hillslope catchment of the Loess Plateau, China, J. Hydrol., 240, 243-263, https://doi.org/10.1016/s0022-1694(00)00362-0, 2001. 
Sun, G., Zhou, G., Zhang, Z., Wei, X., McNulty, S. G., and Vose, J. M.: Potential water yield reduction due to forestation across China, J. Hydrol., 328, 548-558, https://doi.org/10.1016/j.jhydrol.2005.12.013, 2006.

Tian, F., Lu, Y., Fu, B., Yang, Y., Qiu, G., Zang, C., and Zhang, L.: Effects of ecological engineering on water balance under two different vegetation scenarios in the Qilian Mountain, northwestern China, J. Hydrol.-Regional Studies, 5, 324-335, https://doi.org/10.1016/j.ejrh.2015.11.015, 2016.

Wang, L., Wang, Q., Wei, S., Shao, M. A., and Li, Y.: Soil desiccation for Loess soils on natural and regrown areas, Forest Ecol. Manag., 255, 2467-2477, https://doi.org/10.1016/j.foreco.2008.01.006, 2008.

Wang, S., Fu, B. J., Gao, G. Y., Yao, X. L., and Zhou, J.: Soil moisture and evapotranspiration of different land cover types in the Loess Plateau, China, Hydrol. Earth Syst. Sci., 16, 2883-2892, https://doi.org/10.5194/hess-16-2883-2012, 2012.

Wang, S., Fu, B., Gao, G., Liu, Y., and Zhou, J.: Responses of soil moisture in different land cover types to rainfall events in a revegetation catchment area of the Loess Plateau, China, Catena, 101, 122-128, https://doi.org/10.1016/j.catena.2012.10.006, 2013.

Wang, Y., Shao, M. A., Zhu, Y., and Liu, Z.: Impacts of land use and plant characteristics on dried soil layers in different climatic regions on the Loess Plateau of China, Agr. Forest Meteorol., 151, 437-448, https://doi.org/10.1016/j.agrformet.2010.11.016, 2011.

Wei, W., Chen, L. D., Zhang, H. D., and Chen, J.: Effect of rainfall variation and landscape change on runoff and sediment yield from a loess hilly catchment in China, Environ. Earth Sci., 73, 1005-1016, https://doi.org/10.1007/s12665-014-3451-y, 2015.

$\mathrm{Wu}, \mathrm{Y}$. and Chen, J.: Analyzing the water budget and hydrological characteristics and responses to land use in a monsoonal climate river basin in south China, Environ. Manage., 51, 1174-1186, https://doi.org/10.1007/s00267-013-0045-5, 2013.

Xu, Y. D., Fu, B. J., He, C. S., and Gao, G. Y.: Watershed discretization based on multiple factors and its application in the Chinese Loess Plateau, Hydrol. Earth Syst. Sci., 16, 59-68, https://doi.org/10.5194/hess-16-59-2012, 2012.

Yang, L., Wei, W., Chen, L., Chen, W., and Wang, J.: Response of temporal variation of soil moisture to vegetation restoration in semi-arid Loess Plateau, China, Catena, 115, 123-133, https://doi.org/10.1016/j.catena.2013.12.005, 2014.
Zhang, G., Tang, M., and Zhang, X.: Temporal variation in soil detachment under different land uses in the Loess Plateau of China, Earth Surf. Proc. Land., 34, 1302-1309, https://doi.org/10.1002/esp.1827, 2009.

Zhang, X., Srinivasan, R., Debele, B., and Hao, F.: Runoff simulation of the headwaters of the Yellow River using the SWAT model with three snowmelt algorithms, J. Am. Water Resour. As., 44, 48-61, https://doi.org/10.1111/j.1752-1688.2007.00137.x, 2008.

Zhang, X., Srinivasan, R., Arnold, J., Izaurralde, R. C., and Bosch, D.: Simultaneous calibration of surface flow and baseflow simulations: a revisit of the SWAT model calibration framework, Hydrol. Process., 25, 2313-2320, https://doi.org/10.1002/hyp.8058, 2011.

Zhang, X., Izaurralde, R. C., Arnold, J. G., Williams, J. R., and Srinivasan, R.: Modifying the Soil and Water Assessment Tool to simulate cropland carbon flux: Model development and initial evaluation, Sci. Total Environ., 463-464, 810-822, https://doi.org/10.1016/j.scitotenv.2013.06.056, 2013.

Zhao, G., Mu, X., Wen, Z., Wang, F., and Gao, P.: Soil erosion, conservation, and eco-environment changes in the Loess Plateau of China, Land Degrad. Dev., 24, 499-510, https://doi.org/10.1002/ldr.2246, 2013

Zhen, N., Fu, B., Lü, Y., and Zheng, Z.: Changes of livelihood due to land use shifts: A case study of Yanchang County in the Loess Plateau of China, Land Use Policy, 40, 28-35, https://doi.org/10.1016/j.landusepol.2013.05.004, 2014.

Zhou, D., Zhao, S., and Zhu, C.: The Grain for Green Project induced land cover change in the Loess Plateau: A case study with Ansai County, Shanxi Province, China, Ecol. Indic., 23, 88-94, https://doi.org/10.1016/j.ecolind.2012.03.021, 2012.

Zucco, G., Brocca, L., Moramarco, T., and Morbidelli, R.: Influence of land use on soil moisture spatial-temporal variability and monitoring, J. Hydrol., 516, 193-199, https://doi.org/10.1016/j.jhydrol.2014.01.043, 2014.

Zuo, D., Xu, Z., Yao, W., Jin, S., Xiao, P., and Ran, D.: Assessing the effects of changes in land use and climate on runoff and sediment yields from a watershed in the Loess Plateau of China, Science Total Environ., 544, 238-250, https://doi.org/10.1016/j.scitotenv.2015.11.060, 2016. 